\title{
Molecular Signature of Differential Virulence in Natural Isolates of Erwinia amylovora
}

\author{
Dongping Wang, Schuyler S. Korban, and Youfu Zhao
}

First and third authors: Department of Crop Sciences, and second author: Department of Natural Resources and Environmental Sciences, University of Illinois at Urbana-Champaign, Urbana 61801.

Accepted for publication: 21 October 2009.

\begin{abstract}
Wang, D. P., Korban, S. S., and Zhao, Y. F. 2010. Molecular signature of differential virulence in natural isolates of Erwinia amylovora. Phytopathology 100:192-198.

Erwinia amylovora, the causal agent of fire blight, is considered to be a genetically homogeneous species based on physiological, biochemical, phylogenetic, and genetic analysis. However, E. amylovora strains exhibiting differential virulence are isolated from nature. The exopolysaccharide amylovoran and type III secretion system (T3SS) are two major yet separate virulence factors in E. amylovora. The objective of this study was to investigate whether there is a correlation between $E$. amylovora virulence and levels of virulence gene expression. Four wildtype strains (Ea1189, Ea273, Ea110, and CFBP1430), widely used in

Delicious and G16 apple root stock plants but not on susceptible Gala plants. In addition, Ea273 and Ea110 elicited severe hypersensitive responses within shorter periods of time at lower inoculum concentrations than those of Ea1189 and CFBP1430 on tobacco plants. Further molecular analyses have revealed that amylovoran production and expression of both amylovoran ( $a m s G$ ) and T3SS ( $d s p E$ and $h r p L$ ) genes were significantly higher in Ea273 and Ea110 than those in Ea1189 and CFBP1430. Other phenotypes such as swarming motility in these four strains also differed significantly. These results indicate that E. amylovora strains of different origin can be divided into subgroups based on molecular signatures of virulence gene expression. Therefore, these molecular signatures may be used to differentiate E. amylovora strains, which may have taxonomical and evolutionary implications.
\end{abstract} studies of E. amylovora pathogenesis, have been analyzed and compared. E. amylovora strains Ea273 and Ea110 elicited higher severity of disease symptoms than those of Ea1189 and CFBP1430 on apple cv. Golden
Additional keywords: genetic diversity, host range.
Fire blight, caused by the gram-negative bacterium Erwinia amylovora, is a destructive bacterial disease of apple and pear as well as other rosaceous plants. The disease was first observed in 1880 in the Hudson Valley of New York and later spread to New Zealand and across North America, Europe, and the Middle East in the past two centuries $(45,47)$. Recently, a similar bacterial shoot blight disease reported in South Korea and Japan, caused by Erwinia pyrifoliae, affects only Asian pear (17).

E. amylovora belongs to the family Enterobacteriaceae and is closely related to many important human and animal pathogens such as Escherichia coli, Yersinia pestis, Salmonella enterica, and Shigella flexneri. Previous studies have revealed that the exopolysaccharide (EPS) amylovoran and type III secretion system (T3SS) are two major virulence factors in Erwinia amylovora to cause disease $(4,26,35,55)$. Moreover, the EPS amylovoran is an acidic heteropolymer composed of pentasaccharide repeating units (32) and may function in plugging plant vascular tissues, suppressing plant basal defenses, and biofilm formation in planta $(21,40,47)$. In E. amylovora, amylovoran biosynthetic genes are encoded by the ams operon and ams $G$ is the first gene of the operon (5). Expression of the ams operon is regulated by the Rcs phosphorelay system in E. amylovora, which is also essential for pathogenicity (49). On the other hand, the hrp T3SS gene cluster is required for E. amylovora to elicit a hypersensitive response (HR) in nonhost plants and cause disease in host plants. The

Corresponding author: Y. F. Zhao; E-mail address: zhao888@illinois.edu

* The $\boldsymbol{e}$-Xtra logo stands for "electronic extra" and indicates that Figure 2 appears in color online.

doi:10.1094/PHYTO-100-2-0192

(c) 2010 The American Phytopathological Society master regulator of T3SS is HrpL, a member of the ECF subfamily of sigma factors which, in turn, is activated by both the HrpS sigma 54 enhancer-binding protein and the HrpXY twocomponent system (51). HrpL recognizes conserved promoter motifs ( $h r p$ boxes) of structural genes and those genes whose protein products are secreted via T3SS $(50,54)$. One of the secreted proteins, DspE (disease specific protein), is a functional homolog of AvrE in Pseudomonas syringae pv. tomato, and a mutation in $d s p E$ renders the pathogen nonpathogenic $(7,8)$. It has been proven that $\mathrm{DspE}$ is translocated into plant cells and induces cell death in apple and nonhost plants $(6,9,28)$. In a recent study, we have demonstrated that a T3SS island deletion mutant and an ams operon deletion mutant could complement each other in a coinoculation experiment, indicating that these two virulent factors are both necessary to cause disease (55).

E. amylovora is motile in terms of peritrichous flagella (47). Motility of E. amylovora is dependent on temperature, $\mathrm{pH}$, and other environmental signals. In Escherichia coli, the flhDC gene is the master regulator of flagella biosynthesis and swarming motility (14). Products of $f l h D C$ genes positively regulate secondclass (such as $f l i A$ ) or third-class (such as $f l i C$ ) genes for flagella biosynthesis (23). Recently, it has been confirmed that swarming motility is also required for and enhances the virulence of Erwinia amylovora $(2,11)$.

Management of fire blight and international trade of apple and pear have been greatly hindered due to insufficient knowledge of the pathogen, particularly its genetic diversity and host range. It is well known that E. amylovora infects various hosts within the family of Rosaceae, including subfamily Maloideae and Amygdaloideae (29). In addition, some strains are host specific and can only infect Rubus plants within the subfamily of Rosoideae. It has been reported that E. amylovora is a relatively homogeneous 
group of bacteria $(13,43,48)$. However, E. amylovora can be differentiated based on genetic DNA polymorphisms $(20,22,24$, 27,30,31,39,46). These studies have consistently divided $E$. amylovora strains into three major groups of different host range (i.e., strains isolated from Maloideae, from Rosoideae [Rubus spp.], and from Asian pear [now a new species, E. pyrifoliae]) (17). Recently, subtractive hybridization analysis has also detected genetic differences among blight-causing strains of $E$. amylovora of different host specificities. However, there are no observed differences between strains Ea110 and Ea273, both isolated from apple (43).

Among strains isolated from Maloideae, differential virulence has also been observed in different apple cultivars $(33,34)$. It has been shown that E. amylovora strain Ea273 causes higher disease severity on most apple or crabapple genotypes, including Holly, and little or no disease on genotypes Quinte and Novole. In contrast, E. amylovora strain Ea266 appears to be less virulent on Holly but causes severe disease on cv. Quinte, whereas strain E4001A is virulent on all three genotypes. Based on severity of virulence on different apple or crabapple genotypes, E. amylovora strains have been classified as highly virulent (Ea4001a), moderately virulent (Ea273), and low virulent (Ea321) (33). Similar results have been reported for E. amylovora strains isolated from Bulgaria and from both Idaho and Pennsylvania in the United States (42). However, the molecular mechanism underlying the differential virulence in natural isolates of E. amylovora remains unclear.

The goal of this study was to investigate whether there is a relationship between disease severity and levels of major virulence gene expression in E. amylovora strains isolated from Maloideae plants. Four wild-type (WT) E. amylovora strains (Ea273, Ea110, CFBP1430, and Ea1189), widely used in studying pathogenesis of fire blight pathogen, have been analyzed and compared.

\section{MATERIALS AND METHODS}

Bacterial stains and culture media. Bacterial strains and plasmids used in this study were listed in Table 1. The LuriaBertani (LB) medium was used routinely for culturing $E$. amylovora. When necessary, ampicillin was added to the medium at $100 \mu \mathrm{g} \mathrm{ml}^{-1}$. Amylovoran production was determined by growing bacteria in MBMA medium ( $3 \mathrm{~g}$ of $\mathrm{KH}_{2} \mathrm{PO}_{4}, 7 \mathrm{~g}$ of $\mathrm{K}_{2} \mathrm{HPO}_{4}$, $1 \mathrm{~g}$ of $\left[\mathrm{NH}_{4}\right]_{2} \mathrm{SO}_{4}, 2 \mathrm{ml}$ of glycerol, $0.5 \mathrm{~g}$ of citric acid, and $0.03 \mathrm{~g}$ of $\mathrm{MgSO}_{4}$ ) plus $1 \%$ sorbitol, as described previously $(11,49,56)$.

DNA manipulation and sequence analysis. Plasmid DNA purification, polymerase chain reaction (PCR) amplification, isolation of fragments from agarose gels, cloning, restriction enzyme digestion, and T4 DNA ligation were performed using standard molecular procedures (37). DNA sequencing was performed at the Keck Biotechnology Center for Functional and Comparative Genomics at the University of Illinois at Urbana-Champaign. Sequence management and contig assembly were conducted using Sequencher 4.9 software. Database searches were conducted using the BLAST programs at the National Center for Biotechnology Information (www.ncbi.nlm.nih.gov/BLAST) (1).

Construction of promoter-green fluorescent protein fusions for gene expression assays. For gene expression assays, flanking sequences of the $h r p L$ and $d s p E$ open reading frames were used to design primers to amplify DNA fragments. The primer pairs hrpL1-hrpL2 and dspE1-dspE2 with restriction sites (Table 1) were used to amplify 608- and 570-bp DNA fragments from $E$. amylovora WT Ea1189 strain, containing promoter sequences of $h r p L$ and $d s p E$ genes, respectively. PCR products and the promoter-trapping vector pFPV25 were both digested with $K p n \mathrm{I}$ and $X b a \mathrm{I}$ for the $h r p L$ promoter and with SmaI for the $d s p E$ promoter, respectively. The resulting fragments were gel purified, ligated together, and cloned upstream of the promoterless green fluorescent protein $(g f p)$ gene. The final plasmids were designated as pZW2 and pZW3 for the $h r p L$ gene and the $d s p E$ promoter in sense orientation, respectively, and were confirmed by restriction enzyme digestion and sequencing. The $a m s G$ and $f l h D-G F P$ promoter fusion plasmids were constructed and cloned from WT Ea1189 strain as previously reported $(49,56)$.

Virulence assays on apple plants. Virulence assays were carried out as described previously (12,33). Briefly, young leaves, 2 to $4 \mathrm{~cm}$ in length, of Gala, Golden Delicious, and G16 rootstock plants were inoculated with scissors dipped in a pathogen suspension (optical density at $600 \mathrm{~nm}\left[\mathrm{OD}_{600}\right]=0.1$ ). Newly grown young shoots, $\approx 4$ week old, were used in all our inoculation experiments. In total, $\approx 10$ to 15 leaves were inoculated for each strain for Golden Delicious and Gala plants and $\approx 10$ for G16

TABLE 1. Bacterial strains, plasmids, and primers used in this study

\begin{tabular}{|c|c|c|}
\hline $\begin{array}{l}\text { Strains, plasmids, } \\
\text { primers }\end{array}$ & Relevant characters or sequences $\left(5^{\prime}-3^{\prime}\right)^{\mathrm{a}}$ & $\begin{array}{l}\text { Reference } \\
\text { or source }\end{array}$ \\
\hline \multicolumn{3}{|l|}{ Strains } \\
\hline \multicolumn{3}{|c|}{ Erwinia amylovora } \\
\hline $\mathrm{Ea} 273$ & Wild type, isolated from apple, New York, United States & 8 \\
\hline Ea110 & Wild type, isolated from apple, Michigan, United States & 25 \\
\hline CFBP1430 & Wild type, isolated from Crataegus, France & 16 \\
\hline \multicolumn{3}{|l|}{ Escherichia coli } \\
\hline \multicolumn{3}{|c|}{ 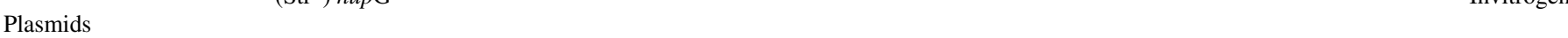 } \\
\hline pFPV25 & $\mathrm{Ap}^{\mathrm{R}}$, GFP-based promoter trap vector containing a promoter-less gfpmut $3 a$ gene & 44 \\
\hline pWDP4 & 721-bp KpnI-XbaI DNA fragment containing promoter sequence of $a m s G$ gene of Ea1189 in pFPV25 & 49 \\
\hline pSN1 ${ }^{\mathrm{b}}$ & 906-bp EcoRI-BamHI DNA fragment containing promoter sequence of $f l h D$ gene of Ea 1189 in pFPV25 & 49 \\
\hline $\mathrm{pZW} 2^{\mathrm{b}}$ & 608-bp $K p n \mathrm{I}-X b a \mathrm{I}$ DNA fragment containing promoter sequence of $h r p L$ gene of Ea1189 in pFPV25 & This study \\
\hline pZW3 & $570-\mathrm{bp} S m a$ I DNA fragment containing promoter sequence of $d s p E$ gene of Ea1189 in pFPV25 in forward orientation & This study \\
\hline \multicolumn{3}{|l|}{ Primers } \\
\hline
\end{tabular}


rootstock plants. All 2-year-old plants were maintained either in the greenhouse or growth chamber at $25^{\circ} \mathrm{C}$ and a photoperiod with $16 \mathrm{~h}$ of light. Disease severity was evaluated and recorded for up to 7 days postinoculation (dpi). Progression of necrosis was recorded using a previously described visual scale (33) as follows: 0 , no necrosis; 1 , necrosis limited to the inoculation point; 2, necrosis reaching the midrib; 3 , necrosis reaching the petiole; 4, necrosis reaching the stem; and 5, necrosis on the main shoot. For each inoculated strain, the necrosis severity index (NSI) is calculated using the following formula:

$$
\mathrm{NSI}=\sum_{i=0}^{5} i N i / 5 N \times 100
$$

where $N_{i}$ is the number of leaves with disease $I$ and $N$ is the number of the sample. The experiments were repeated once.

HR assays on tobacco leaves. For E. amylovora strains Ea1189, Ea273, Ea110, and CFBP1430, bacterial suspensions were grown overnight in LB broth, harvested by centrifugation, and resuspended in $0.5 \times$ sterile phosphate-buffered saline (PBS) with bacterial cells adjusted to concentrations of $10^{6}, 10^{7}$, and $10^{8}$ $\mathrm{CFU} / \mathrm{ml}\left(\mathrm{OD}_{600}=0.1\right.$ and then series diluted 10 - and 100 -fold $)$ in PBS. Eight-week-old tobacco leaves were inoculated with bacterial suspensions and incubated in a humidity chamber at $28^{\circ} \mathrm{C}$. $\mathrm{HR}$ response was recorded at 6,12 , and $24 \mathrm{~h}$ postinoculation (hpi).

Cetylpyrimidinium chloride assay for determining amylovoran concentration. The amylovoran concentration in supernatants of bacterial cultures was quantitatively determined by a turbidity assay with cetylpyrimidinium chloride (CPC), as previously described $(3,49,56)$. Briefly, bacterial suspensions were grown overnight in LB broth with or without antibiotic, harvested by centrifugation, and washed with PBS three times. After the final wash, the bacterial pellet was resuspended in $200 \mu \mathrm{l}$ of PBS. A total of $100 \mu \mathrm{l}$ of bacterial suspension was inoculated into $10 \mathrm{ml}$ of MBMA medium with $1 \%$ sorbitol. Bacterial cells were pelleted 2 to $3 \mathrm{dpi}$ at $28^{\circ} \mathrm{C}$ with shaking. Following centrifugation, $50 \mu \mathrm{l}$ of CPC at $50 \mathrm{mg} \mathrm{m}^{-1}$ was added to $1 \mathrm{ml}$ of supernatant. After $10 \mathrm{~min}$ of incubation at room temperature, the amylovoran concentration was determined by measuring $\mathrm{OD}_{600}$ turbidity. The final concentration of amylovoran production was normalized for a cell density of 1.0. For each strain tested, the experiment was repeated at least three times.

Swarming motility assay. Bacterial suspensions were grown overnight in LB broth, harvested by centrifugation, washed with PBS once, and resuspended in $200 \mu \mathrm{l}$ of PBS. Then, bacterial suspensions were diluted $10 \times$ in water, and $5 \mu$ of the diluted bacterial suspension was plated onto the center of swarming agar plates (10 g tryptone, $5 \mathrm{~g} \mathrm{NaCl}$, and $3 \mathrm{~g}$ of agar per 1 liter) as previously described $(18,56)$. Swarming diameters were determined following incubation at $28^{\circ} \mathrm{C}$ for up to 3 days. The experiments were repeated at least three times.

GFP reporter gene assay by flow cytometry. The BD FACSCanto flow cytometer was used to monitor the GFP intensity of WT strains containing the corresponding promoter-GFP construct $(19,49)$. For in vitro ams $G$ gene expression, strains containing the $a m s G$ promoter-GFP fusion plasmid were grown in

TABLE 2. Disease severity of wild-type strains on apple plants with different resistance levels

\begin{tabular}{lccc}
\hline & \multicolumn{3}{c}{$\mathrm{NSI} \pm \mathrm{SD}^{\mathrm{a}}$} \\
\cline { 2 - 4 } Bacterial strains & Gala & Golden Delicious & \multicolumn{1}{c}{ G16 } \\
\hline Ea1189 & $92.0 \pm 7.3$ & $21.2 \pm 8.7$ & $10.4 \pm 2.0$ \\
Ea273 & $84.2 \pm 5.1$ & $80.2 \pm 11.9$ & $56.5 \pm 10.9$ \\
Ea110 & $90.8 \pm 5.2$ & $75.9 \pm 8.8$ & $54.0 \pm 1.0$ \\
CFBP1430 & $86.0 \pm 5.7$ & $35.8 \pm 9.8$ & $20.2 \pm 10.2$ \\
\hline
\end{tabular}

${ }^{a}$ Mean necrosis severity index (NSI) (10 to 15 inoculated leaves/shoots) \pm standard deviation (SD) 7 days postinoculation.
LB overnight, harvested, and resuspended in water. Bacterial suspensions were reinoculated in MBMA broth with $1 \%$ sorbitol and grown at $28^{\circ} \mathrm{C}$ with shaking for up to 3 days. Bacterial cultures were then harvested by centrifugation, washed once with PBS, and then resuspended in PBS for flow cytometry assay.

For in vivo gene expression assay, bacterial strains harboring $a m s G, h r p L$, and $d s p E$ promoters were inoculated onto immature pear fruit as described previously (49). Following incubation at $26^{\circ} \mathrm{C}$ for up to 2 days, bacterial cells were collected by either washing or centrifugation, washed twice with PBS, and then resuspended in PBS for flow cytometry assay.

For flhDC gene expression, WT strains containing the flhDC promoter GFP fusion plasmid were grown on swarming plates as described above. Following incubation for 2 days at $28^{\circ} \mathrm{C}$, bacterial cells were collected, washed, and resuspended in PBS for flow cytometry assay. Flow cytometry was performed using a BD LSRII 10 parameter multilaser analyzer (BD Bioscience, San Jose, CA).

Data were collected for a total of 100,000 events and statistically analyzed by gating using flow cytometry software FCS Express V3 (De Novo Software, Los Angeles). A geometric mean was calculated for each sample. Each treatment was performed in triplicate and each experiment was repeated three times.

\section{RESULTS}

E. amylovora WT strains induced different levels of disease severity on apple plants. Disease symptoms caused by WT strains on Gala appeared 2 days postinfection and quickly spread throughout the leaf and into petioles and, finally, into the primary shoot. Ooze production appeared on petioles $3 \mathrm{dpi}$. The NSI on Gala at 7 dpi was 90.2, 84.2, 90.8, and 86.0 for strains Ea1189, Ea273, Ea110, and CFBP1430, respectively (Table 2). On Gold Delicious, disease symptoms caused by Ea273 and Ea110 appeared 2 dpi and necrosis progressed through midribs, lateral veins and lamina, and, eventually, whole leaf blades; then spreading into the stem after 1 week. Droplets of ooze production were also observed on the stem adjacent to infected leaves. In contrast, symptoms caused by Ea1189 and CFBP1430 were visible 4 dpi but these did not spread throughout the leaves even after 1 week postinoculation. The NSI values for Ea273 and Ea110 at 7 dpi were approximately two- to fourfold higher than those of Ea1189 and CFBP1430 (Table 2). On G16, Ea273 and Ea110 caused leaf necrosis $4 \mathrm{dpi}$, and bacteria moved to the nearby petiole $7 \mathrm{dpi}$. However, most leaves infected by Ea1189 and CFBP1430 showed necrosis along the cut area, and disease symptoms spread to midribs of only a few leaves. The NSI values for Ea273 and Ea110 at 7 dpi were more than twofold higher than those of Ea1189 and CFBP1430 (Table 2).

E. amylovora WT strains produced different amounts of amylovoran, and amylovoran gene expression was also different. E. amylovora utilizes two major virulence factors, amylovoran and T3SS, to cause disease. Initially, amylovoran production in these four strains was evaluated. When different WT strains were grown on LB plates, different mucoid phenotypes were observed (Fig. 1A), indicating that these strains may produce different amount of exopolysaccharide. Colonies of Ea273 and Ea110 strains were much more mucoid than those of Ea1189 and CFBP1430 strains (Fig. 1A). Then, amylovoran production in the supernatant of bacterial cultures was quantitatively determined using a turbidity assay with CPC, as previously described $(3,49)$. All four WT strains had exhibited varying levels of amylovoran production in vitro (Fig. 1B). The $\mathrm{OD}_{600}$ values of amylovoran production were 0.1 and 0.28 for Ea1189 and CFBP1430, respectively, $48 \mathrm{~h}$ after inoculation, and 1.83 and 1.59 for Ea273 and Ea110, respectively (Fig. 1B). These results indicated that Ea273 and Ea110 produced higher amounts of amylovoran than Ea1189 and CFBP1430. 
In order to correlate amylovoran production with amylovoran biosynthesis gene expression, the promoter of the $a m s G$ gene, the first gene in the amylovoran operon, was cloned into a promoterless GFP reporter vector and the $a m s G$ promoter-GFP fusion
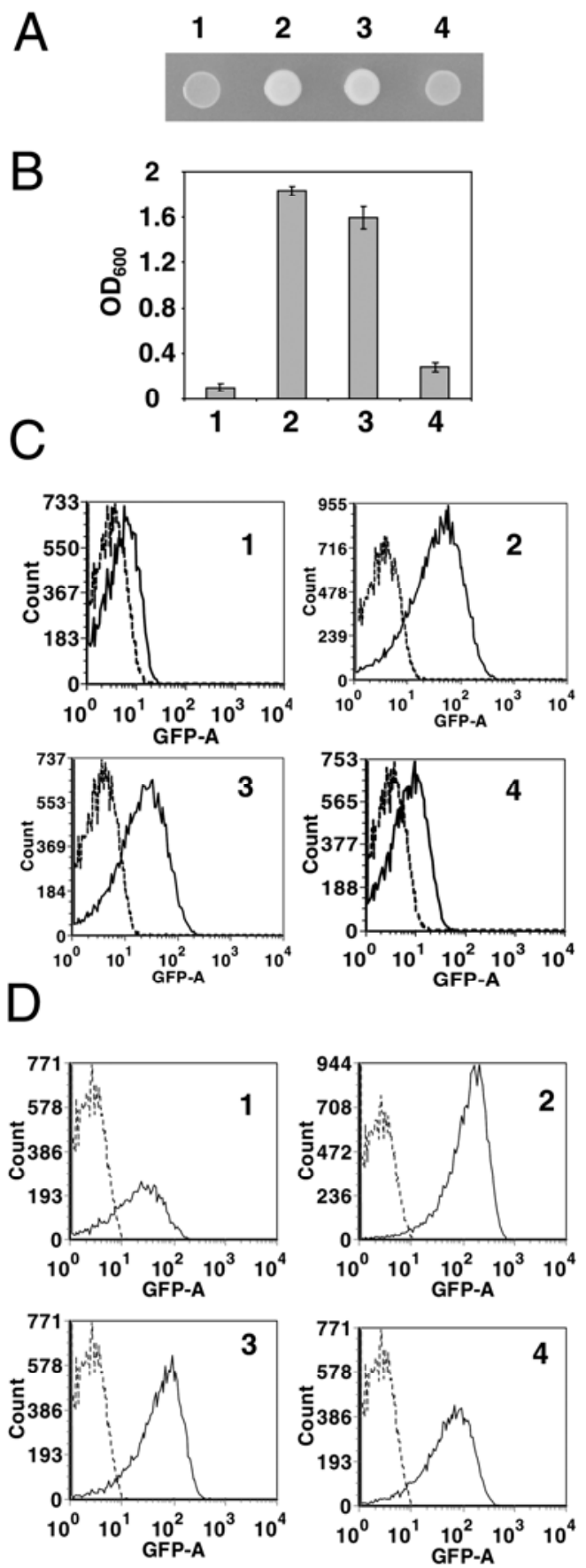

Fig. 1. A, Growth of wild-type (WT) strains on Luria-Bertani plates 24 h postinoculation, showing the mucoid phenotype of Ea273 and Ea110. OD $600=$ optical density at $600 \mathrm{~nm}$. B, Amylovoran production of WT strains in vitro. Bacterial strains were grown in MBMA media with $1 \%$ sorbitol for $48 \mathrm{~h}$ at $28^{\circ} \mathrm{C}$ with shaking. The amount of amylovoran was measured with the cetylpyrimidinium chloride assay and normalized to a cell density of 1 . Data points represent means of three replicates \pm standard deviations. Similar results were obtained in three independent experiments. $\mathbf{C}$, The ams $G$ gene expression in WT strains in vitro. Green fluorescent protein (GFP) intensity in WT strains containing the ams $G$ promoter-GFP fusion plasmid was measured by flow cytometry. D, The ams $G$ gene expression in WT strains on immature pear fruit $48 \mathrm{~h}$ postinoculation. GFP intensity in WT strains containing the ams $G$ promoter-GFP fusion plasmid was measured by flow cytometry. The experiment was repeated at least three times and similar results were obtained. Dashed lines = vector control. 1: Ea1189, 2: Ea273, 3: Ea110, 4: CFBP1430. plasmid was introduced into four WT strains (49). The GFP intensity was measured by flow cytometry in WT strains 48 hpi in liquid medium. The $a m s G$ gene was expressed at a GFP intensity value of 1.70 and 2.25 (geometric mean) for Ea1189 and CFBP1430, respectively, compared with a geometric mean value of 1.50 for the vector control (Table 2). The geometric mean values of the GFP intensities of the ams $G$ promoter were 40.55 and 10.67 for Ea273 and Ea110, respectively (Fig. 1C). In addition, ams $G$ gene expression was also determined for the four strains carrying the plasmid following inoculation onto immature pear fruit. AmsG gene expression for all four WT strains was upregulated in immature pear fruit compared with that observed in the liquid medium (Table 2). Moreover, GFP intensity values were $3.95,11.85,103.23$, and 21.88 (geometric mean) for Ea1189, CFBP1430, Ea273, and Ea110, respectively (Fig. 1D). These results indicated that expression levels of the ams $G$ gene were significantly different among the four WT strains and were correlated with amylovoran production. In addition, these results also demonstrated that the $a m s G$ gene was induced more than twofold in planta, as reported previously (49).

E. amylovora WT strains showed different HR-eliciting ability on tobacco. The four WT strains showed varying degrees of HR-inducing ability (Fig. 2). At a low concentration of inoculum $\left(10^{6} \mathrm{CFU} / \mathrm{ml}\right)$, only Ea273 and Ea110 induced visible $\mathrm{HR}$ at 24 hpi (Fig. 2). At an intermediate concentration of inoculum $\left(10^{7} \mathrm{CFU} / \mathrm{ml}\right), \mathrm{Ea} 273$ and Ea110 induced visible HR at 6 hpi and HR response was severe at 24 hpi. At a high inoculum concentration $\left(10^{8} \mathrm{CFU} / \mathrm{ml}\right), \mathrm{Ea} 273$ and Ea110 induced strong $\mathrm{HR}$ as early as 6 hpi. On the other hand, Ea1189 and CFBP1430 elicited no $\mathrm{HR}$ at $10^{6} \mathrm{CFU} / \mathrm{ml}$; very weak $\mathrm{HR}$ at $10^{7} \mathrm{CFU} / \mathrm{ml} 24 \mathrm{hpi}$, visible $\mathrm{HR}$ at $10^{8} \mathrm{CFU} / \mathrm{ml} 6 \mathrm{hpi}$, and strong HR response at $24 \mathrm{hpi}$ (Fig. 2). These results indicated that different E. amylovora WT strains exhibited different capabilities in inducing HR response on tobacco, suggesting that secretion and translocation of harpin or other effectors differs greatly in these strains.

$E$. amylovora WT strains had different levels of T3SS gene expression. Next, we examined whether the T3SS master regulator $h r p L$ gene and the major effector gene $d s p E$ were also differentially expressed in these WT strains. The $h r p L$ gene was expressed at GFP intensities of 2.64, 4.07, 9.89, and 5.43 (geometric mean) for Ea1189, CFBP1430, Ea273, and Ea110, respectively (Table 3). The GFP intensity values for $d s p E$ promoter were $2.02,6.55,15.11$, and 11.27 (geometric mean) for Ea1189,

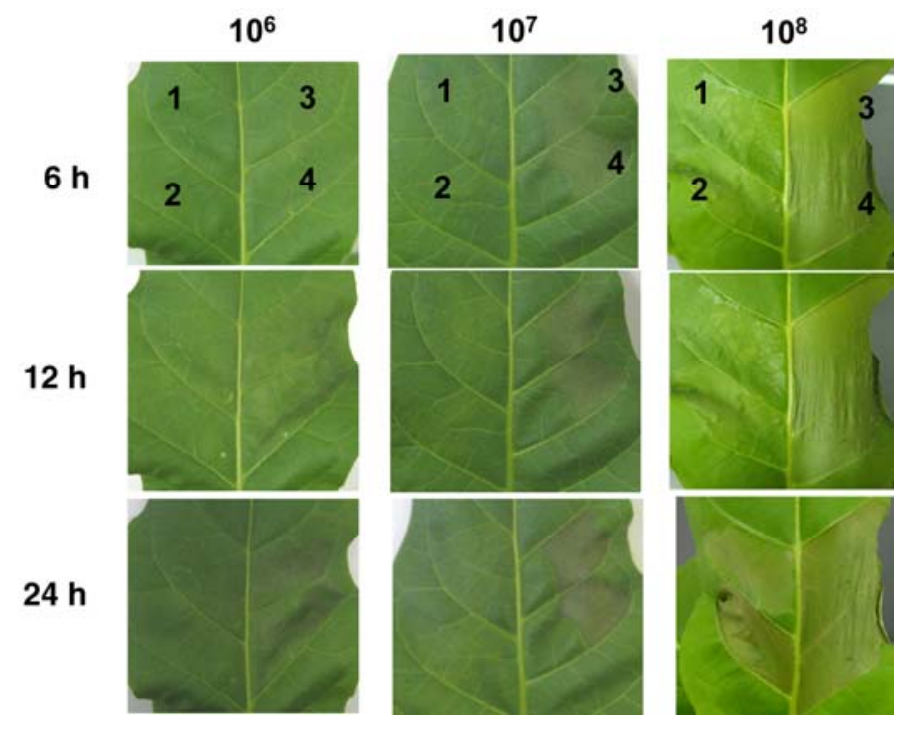

Fig. 2. Hypersensitive response (HR) assay on tobacco leaves. Eight-week-old tobacco leaves were infiltrated with different wild-type strains at the concentration of $1 \times 10^{6}, 1 \times 10^{7}$, and $1 \times 10^{8}$. HR was recorded 6,12 , and $24 \mathrm{~h}$ postinoculation. 1: Ea1189: 2: CFBP1430; 3: Ea110; 4: Ea273. 
CFBP1430, Ea273, and Ea110, respectively (Table 3). These results further indicated that T3SS regulatory and effector genes were expressed at different levels in these four WT strains, and these were also positively correlated with their capabilities in eliciting HRs on tobacco plants.

E. amylovora WT strains exhibited different swarming motility phenotypes. A regular circular swarming motility was observed for Ea1189, Ea273, Ea110, and CFBP1430 at $24 \mathrm{~h}$ (Fig. $3 \mathrm{~A})$. The diameters of these circles were $\approx 1.1,1.32,1.35$, and $1.08 \mathrm{~cm}$ for Ea1189, Ea273, Ea110, and CFBP1430, respectively, from an original spot of $0.6 \mathrm{~cm}$ (Fig. 3B). After 72 hpi, Ea1189 continued to show regular circle swarming motility, and the diameter was $\approx 5.7 \mathrm{~cm}$. Interestingly, Ea273 and Ea110 exhibited different swarming patterns compared with Ea1189 and CFBP1430. Ea273 demonstrated a sunflower-like motility and swarming diameter of $\approx 8.6 \mathrm{~cm}$, almost covering the whole plate (Fig. 3B). Ea110 and CFBP1430 showed irregular swarming motilities, and diameters were $\approx 7.3$ and $4.6 \mathrm{~cm}$, respectively (Fig. 3B). These results indicated that the four strains exhibited different swarming motility phenotypes.

To correlate swarming motility with $f l h D$ gene expression, a flhD promoter-GFP fusion plasmid was introduced into WT strains (49). The GFP intensity values of the $f l h D$ promoter in Ea1189, Ea273, Ea110, and CFBP1430 were $\approx 2.88$, 287.73, 14.36, and 10.17 at $24 \mathrm{~h}$ (Table 3). These results indicated that swarming motilities of Ea1189, Ea273, Ea110, and CFBP1430 correlated with the $f l h D$ gene expression, the master regulator of flagella biosynthesis.

\section{DISCUSSION}

Early studies of the fire blight pathogen E. amylovora have revealed that two virulence factors, T3SS and amylovoran, are strictly required for inciting disease on host plants $(5,35,41$, $52,55)$. In this study, differential virulence exists in natural isolates of E. amylovora within the group of Moloideae strains (mainly Malus spp.). Moreover, a positive correlation between bacterial virulence on relatively resistant genotypes, such as Golden Delicious, and the expression or production of major virulence factors such as HrpL, DspE, and amylovoran in $E$. amylovora WT strains has been demonstrated. These results indicated that, although E. amylovora as a whole is a genetically homogeneous pathogen, the pathogen among Maloideae strains

TABLE 3. Green fluorescent protein (GFP) fluorescence intensity in wild-type strains containing ams $G, h r p L, d s p E$, and $f l h D$ promoter-GFP fusion plasmid

\begin{tabular}{|c|c|c|c|}
\hline \multirow[b]{2}{*}{ Bacterial strains } & \multirow[b]{2}{*}{ Plasmid (gene) $)^{\mathrm{a}}$} & \multicolumn{2}{|c|}{$\begin{array}{l}\text { GFP intensity (geometric mean } \\
\pm \text { standard deviation) })^{b}\end{array}$} \\
\hline & & In vitro & In vivo \\
\hline Ea1189 & pWDP4 (amsG) & $1.70 \pm 0.09$ & $3.95 \pm 0.12$ \\
\hline $\mathrm{Ea} 273$ & pWDP4 $(a m s G)$ & $40.55 \pm 0.02$ & $103.23 \pm 0.02$ \\
\hline Ea110 & pWDP4 (amsG) & $10.67 \pm 0.05$ & $21.88 \pm 1.15$ \\
\hline CFBP1430 & pWDP4 (amsG) & $2.25 \pm 0.04$ & $11.85 \pm 0.05$ \\
\hline Ea1189 & pZW2 (hrpL) & ND & $2.64 \pm 0.04$ \\
\hline $\mathrm{Ea} 273$ & pZW2 (hrpL) & ND & $9.89 \pm 0.14$ \\
\hline Ea110 & pZW2 (hrpL) & ND & $5.43 \pm 0.09$ \\
\hline CFBP1430 & pZW2 (hrpL) & ND & $4.07 \pm 0.17$ \\
\hline Ea1189 & pZW3 (dspE) & ND & $2.02 \pm 0.04$ \\
\hline Ea273 & pZW3 (dspE) & ND & $15.11 \pm 0.81$ \\
\hline Ea110 & pZW3 (dspE) & ND & $11.27 \pm 0.24$ \\
\hline CFBP1430 & pZW3 (dspE) & ND & $6.55 \pm 0.30$ \\
\hline Ea1189 & pSN1 $(f l h D)$ & $2.88 \pm 0.13$ & ND \\
\hline $\mathrm{Ea} 273$ & pSN1 $(f l h D)$ & $287.73 \pm 10.02$ & ND \\
\hline Ea110 & pSN1 $(f l h D)$ & $14.36 \pm 0.95$ & ND \\
\hline CFBP1430 & pSN1 $(f l h D)$ & $10.17 \pm 1.17$ & ND \\
\hline
\end{tabular}

a Promoter-GFP fusion plasmid.

${ }^{b}$ In vitro means bacteria were grown in MBMA medium or on swarming plates and in vivo means bacteria were inoculated onto immature pear fruits; $\mathrm{ND}=$ not determined . may adapt to different hosts, thus maintaining a population capable of eliciting different levels of diseases on different host plants of varying levels of resistance.

In a previous study, we showed that E. amylovora WT strains (Ea1189, Ea110, and CFBP1430) have similar bacteria growth and cause similar diseases on immature pear fruit (53). However, significant differences in the disease development and severity have been observed for the four WT strains on moderate and highly resistant apple genotypes. This low expression of virulence factors in strains Ea1189 and CFBP1430 is likely to be sufficient for the pathogen to cause disease on immature pear fruit and susceptible apple genotypes such as Gala. Perhaps, it is also likely that these strains are virulent enough to cause disease on susceptible plant genotypes. In another experiment, similar amounts of ooze production (amylovoran) of the four WT strains have been observed on immature pear fruit (data not shown). This indicates that different strains of WT may synthesize similar amounts of amylovoran in immature pear fruit, although $a m s G$ gene expression is different in these strains both in planta and in vitro.

It has previously reported that different plant genotypes react differently with different strains of the fire blight pathogen $(33,34)$. Our results further indicate that E. amylovora may have evolved to adapt to different host plants by changing its level of virulence gene expression or its ability to cause disease. We would argue that plant bacterial pathogens do not intend to kill their host plants in order to survive but still need sufficient weapons to conquer their host plants to acquire nutrients. A similar observation has been reported for survival of Ralstonia solanacearum in soil and in the plant host by changing its phenotype (phenotype conversion through the phcA gene) (38). Our results suggest that bacterial strains isolated from different apple genotypes of varying levels of resistance may have different

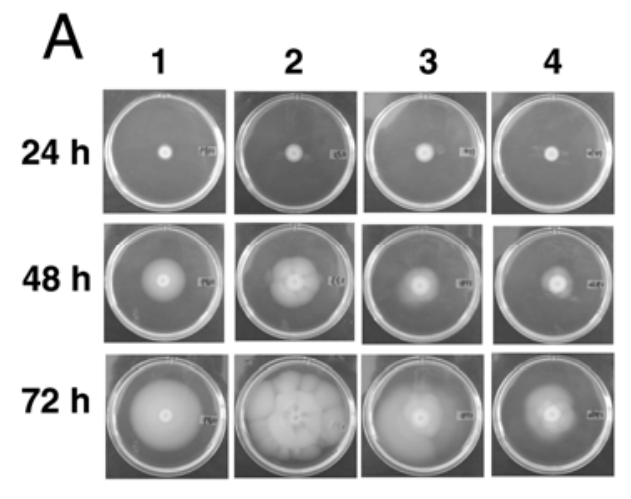

B

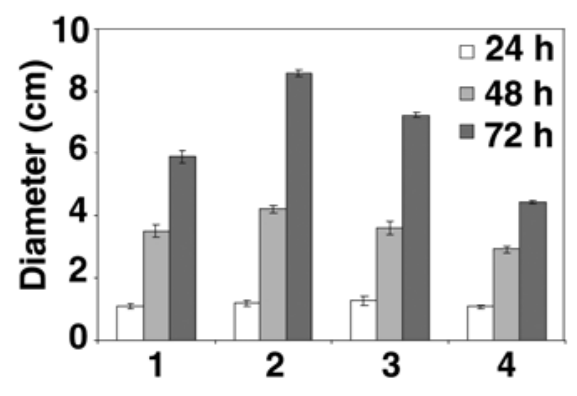

Fig. 3. Swarming motility assay. A, Comparison of motility on swarming plates for different wild-type (WT) strains. Bacterial strains were spotted at the center of the swarming plate $(0.3 \%$ agar $)$ and incubated at $28^{\circ} \mathrm{C}$. Pictures were taken at 24,48 , and $72 \mathrm{~h}$ postinoculation. B, Comparison of the swarming distance of WT strains. The diameters of the swarming circle were measured at 24,48 , and $72 \mathrm{~h}$ postinoculation. For irregular movement, we measured the longest point. Data points represent means of three replicates \pm standard deviations. Similar results were obtained in three independent experiments. 1: Ea1189, 2: Ea273, 3: Ea110, 4: CFBP1430. 
capabilities to cause disease. Thus, only strains with sufficient virulence can survive during their interaction with host plants. We cannot trace back these four bacterial strains to their original plant host genotypes, and the number of samples used in this study is limited; therefore, further studies are warranted to explore this hypothesis.

The key question remains as to why these strains have different levels of virulence by expressing different levels of virulence genes. In other words, what is the molecular mechanism underlying these differences? Genetic studies have revealed that, in $E$. amylovora, a network of genes may control expression of various virulence genes, including global regulators such as the histonelike nucleoid-structuring protein $\mathrm{H}-\mathrm{NS}$, and the two-component systems GrrA/GrrS and EnvZ/OmpR $(18,56)$. Previous studies have indicated that amylovoran production in hns, grrA, grrS, envZ, and $o m p R$ mutants of Ea1189 is similar to that of Ea273 and Ea110 WT strains (56). Similar results have also been obtained for $h r p L$ and $d s p E$ gene expression in ompR/grrA mutants (Y. Zhao, unpublished data). However, these regulatory genes remain intact in Ea273 and Ea110 strains. Other phenotypes, such as swarming motility, remain quite different between Ea1189 mutants and those of Ea273 and Ea110 WT strains. In addition, it is well known that GrrSA positively controls the expression of one to five genes specifying small RNAs (sRNAs), thus upregulating the production of proteins that are otherwise repressed by SRNAs (RsmA/CsrA). These results suggest that differences among the four WT strains cannot be simply explained by one or a few regulatory genes. It is tempting to speculate that genes or sRNAs regulated by either these global regulators or host factors sensed by these regulators may contribute to these differences because host-pathogen interaction is a two-way system. Furthermore, we cannot exclude the possibility that complement of effectors may also contribute to the differential virulence of the WT strains.

Swarming is a form of social motility that shares many similarities with biofilm communities that are notable for their high resistance to antimicrobial agents (15). Recent studies have demonstrated that swarming motility also leads to increased production of virulence factors such as genes encoding for EPS and T3SS and its effectors $(23,36)$. In E. amylovora, swarming motility appears to aid in its invasion of apple blossoms and enhances virulence of WT strains on apple seedlings $(2,11)$. In this study, swarming motility appears to be correlated with virulence of WT strains on resistant apple genotypes.

In summary, our findings support the hypothesis that virulence of E. amylovora cannot be simply explained by levels of virulence gene expression. There are specific interactions that may take place between apple genotypes and strains of E. amylovora. Our future work will focus on identifying genetic determinants responsible for controlling the observed differential virulence and virulence gene expression in these WT strains.

\section{ACKNOWLEDGMENTS}

This work was funded by the United States Department of Agriculture (USDA) Cooperative State Research, Education and Extension Service (Hatch project no. Illu-802-317), the Illinois C-FAR sentinel project (08I020-3-SEN), the USDA-NIFA-SCRI and Agriculture and Food Research Initiative (AFRI), and the Agricultural Experiment Station of Illinois. We thank G. W. Sundin and G. McGhee at the Michigan State University for providing the immature pear fruit used in this experiment.

\section{LITERATURE CITED}

1. Altschul, S. F., Madden, T. L., Schaffer, A. A., Zhang, J., Zhang, Z., Miller, W., and Lipman, D. J. 1997. Gapped BLAST and PSI-BLAST: A new generation of protein database search programs. Nucleic Acids Res. 25:3389-3402.

2. Bayot, R. G., and Ries S. M. 1986. Role of motility in apple blossom infection by Erwinia amylovora and studies of fire blight control with attractant and repellent compounds. Phytopathology 76:441-445.

3. Bellemann, P., Bereswill, S., Berger, S., and Geider, K. 1994. Visualization of capsule formation by Erwinia amylovora and assays to determine amylovoran synthesis. Int. J. Biol. Macromol. 16:290-296.

4. Bellemann, P., and Geider, K. 1992. Localization of transposon insertions in pathogenicity mutants of Erwinia amylovora and their biochemical characterization. J. Gen. Microbiol. 138:931-940.

5. Bernhard, F., Coplin, D., and Geider, K. 1993. A gene cluster for amylovoran synthesis in Erwinia amylovora: Characterization and relationship to cps genes in Erwinia stewartii. Mol. Gen. Genet. 239:158-168.

6. Bocsanczy, A. M., Nissinen, R. M., Oh, C.-S., and Beer, S. V. 2008. HrpN of Erwinia amylovora functions in the translocation of DspA/E into plant cells. Mol. Plant Pathol. 9:425-434.

7. Bogdanove, A. J., Bauer, D. W., and Beer, S. V. 1998. Erwinia amylovora secretes DspE, a pathogenicity factor and functional AvrE homolog, through the Hrp (type III secretion) pathway. J. Bacteriol. 180:2244-2247.

8. Bogdanove, A. J., Kim, J. F., We, Z.-M., Kolchinsky, I., P., Charkowski, A. O., Conlin, A. K., Collmer, A., and Beer, S. V. 1998. Homology and functional similarity of an hrp-linked pathogenicity locus, $d s p E F$, of Erwinia amylovora and the avirulence locus avrE of Pseudomonas syringae pathovar tomato. Proc. Natl. Acad. Sci. USA 95:1325-1330.

9. Boureau, T., ElMaarouf-Bouteau, H., Garnier, A., Brisset, M. N., Perino, C., Pucheu, I., and Barny, M. A. 2006. DspA/E, a type III effector essential for Erwinia amylovora pathogenicity and growth in planta, induces cell death in host apple and nonhost tobacco plants. Mol. PlantMicrobe Interact. 19:16-24.

10. Burse, A., H. Weingart, and M. S. Ullrich. 2004. The phytoalexininducible multi-drug efflux pump, AcrAB, contributes to virulence in the fire blight pathogen, Erwinia amylovora. Mol. Plant-Microbe Interact.17:43-54.

11. Cesbron, S., Paulin, J. P., Tharaud, M., Barny, M. A., and Brisset, M. N. 2006. The alternative sigma factor HrpL negatively modulates the flagellar system in the phytopathogenic bacterium Erwinia amylovora under $h r p$-inducing conditions. Fems. Microbiol. Lett. 257:221-227.

12. Duron, M., Paulin, J. P., and Brisset, M. N. 1987. Use of in vitro propagated material for rating fire blight susceptibility. Acta Hortic. 217:317-324.

13. Elrod, R. P. 1941. Serological studies of the Erwineae. I. Erwinia amylovora. Bot. Gaz. 103:123-131.

14. Francez-Charlot, A., Laugel, B., Van Gemert, A., Dubarry, N., Wiorowski, F., Castanie-Cornet, M. P., Gutierrez, C., and Cam, K. 2003. RcsCDB His-Asp phosphorelay system negatively regulates the $f l h D C$ operon in Escherichia coli. Mol. Microbiol. 49:823-832.

15. Fraser, G. M., and Hughes, C. 1999. Swarming motility. Curr. Opin. Microbiol. 2:630-635.

16. Gaudriault, S., Malandrin, L., Paulin, J. P., and Barny, M. A. 1997. DspA, an essential pathogenicity factor of Erwinia amylovora showing homology with AvrE of Pseudomonas syringae, is secreted via Hrp secretion pathway in a DspB-dependent way. Mol. Microbiol. 26:1057-1069.

17. Geider, K., Auling, G., Jakovljevic, V., and Völksch, B. 2009. A polyphasic approach assigns the pathogenic Erwinia strains from diseased pear trees in Japan to Erwinia pyrifoliae. Lett. Appl. Microbiol. 48:324330.

18. Hildebrand, M., Aldridge, P., and Geider, K. 2006. Characterization of hns genes from Erwinia amylovora. Mol. Genet. Genomics 275:310-319.

19. Jacobi, C. A., Roggenkamp, A., Rakin, R., Zumbihl, L., Leitritz, L., and Heesemann, J. 1998. In vitro and in vivo expression studies of yopE from Yersinia enterocolitica using the $g f p$ reporter gene. Mol. Microbiol. 30:865-882.

20. Kim, J.-H., Beer, S. V., Zumoff, C. H., Gustafson, H. L., Aldwinckle, H. S., and Tanii, A. 1996. Characterization of Erwinia amylovora strains from different hosts and geographical areas. Acta Hortic. 411:183-185.

21. Koczan, J., McGrath, M., Zhao, Y. F., and Sundin, G. W. 2008. Biofilm formation in Erwinia amylovora: implications in pathogenicity. Acta Hortic. 793:67-71.

22. Laby, R. J., and Beer, S. V. 1992. Hybridization and functional complementation of the hrp gene cluster from Erwinia amylovora strain Ea321 with DNA of the other bacteria. Mol. Plant-Microbe Interact. 5:412-419.

23. Lai, S., Tremblay, J., and Déziel, E. 2009. Swarming motility: a multicellular behaviour conferring antimicrobial resistance. Environ. Microbiol. 11:126-136.

24. Lecomte, P., Manceau, C., Paulin, J.-P., and Keck, M. 1997. Identification by PCR analysis on plasmid pEA29 of isolates of Erwinia amylovora responsible of an outbreak in central Europe. Eur. J. Plant Pathol. 103:9198.

25. McGhee, G. C., and Jones, A. L. 2000. Complete nucleotide sequences of ubiquitous plasmid pEA29 from Erwinia amylovora strain Ea88: gene organization and intraspecies variation. Appl. Environ. Microbiol. 66:4897-4907. 
26. McGhee, G. C., and Sundin, G. W. 2008. Thiamin biosynthesis and its influence on exopolysaccharide production: a new component of virulence identified on Erwinia amylovora plasmid pEA29. Acta Hortic. 793:271-277.

27. McManus, P. S., and Jones, A. L. 1995. Genetic fingerprinting of Erwinia amylovora strains isolated from tree-fruit crops and Rubus spp. Phytopathology 85:1547-1553.

28. Meng, X., Bonasera, J. M., Kim, J. F., Nissinen, R. M., and Beer S. V. 2002. DspE of Erwinia amylovora interacts with receptor kinases of apple. Acta Hortic. 590:463-466.

29. Mohan, S. K., and Thomson, S. V. 1996. An outbreak of fire blight in plums. Acta Hortic. 411:73-76.

30. Momol, E. A., Momol, M. T., Norelli, J. L., Beer, S. V., Burr, T. J., and Aldwinckle, H. S. 1999. Relatedness of Erwinia amylovora strains based on amplified 16S-23S ribosomal DNA restriction enzyme analysisARDREA. Acta Hortic. 498:55-59.

31. Momol, M. T., Momol, E. A., Lamboy, W. F., Norelli, J. L., Beer, S. V., and Aldwinckle, H. S. 1997. Characterization of Erwinia amylovora strains using random amplified polymorphic DNA fragments (RAPDs). J. Appl. Microbiol. 82:389-398.

32. Nimtz, M., Mort, A., Domke, T., Wray, V., Zhang, Y., Qiu, F., Coplin, D., and Geider, K. 1996. Structure of amylovoran, the capsular exopolysaccharide from the fire blight pathogen Erwinia amylovora. Carbohydr. Res. 287:59-76.

33. Norelli, J. L., Aldwinckle, H. S. and Beer, S. V. 1984. Differential host $\times$ pathogen interactions among cultivars of apple and strains of Erwinia amylovora. Phytopathology 74:136-139.

34. Norelli, J. L., Aldwinckle, H. S. and Beer, S. V. 1986. Differential susceptibility of Malus spp. cultivars Robusta 5, Novole, and Ottawa 523 to Erwinia amylovora. Plant Dis. 70:1017-1019.

35. Oh, C. S., and Beer, S. V. 2005. Molecular genetics of Erwinia amylovora involved in the development of fire blight. FEMS Microbiol. Lett. 253:185-192.

36. Overhage, J., Bains, M., Brazas, M. D., and Hancock, R. E. W. 2008. Swarming of Pseudomonas aeruginosa is a complex adaptation leading to increased production of virulence factors and antibiotic resistance. J. Bacteriol. 190:2671-2679.

37. Sambrook, J., and Russel, D. W. 2001. Molecular Cloning: A Laboratory Manual. Cold Spring Harbor Laboratory Press, Cold Spring Harbor, NY.

38. Schell, M. A. 2000. Control of virulence and pathogenicity genes of Ralstonia solanacearum by an elaborate sensory array. Annu. Rev. Phytopathol. 38:263-292.

39. Schwartz, T., Berbhard, F., Theiler, R., and Geider, K. 1991. Diversity of the fire blight pathogen in production of dihydrophenyalanine, a virulence factor of some Erwinia amylovora strains. Phytopathology 81:873-878.

40. Sjulin, T. M., and Beer, S. V. 1978. Mechanism of wilt induction by amylovoran in Cotoneaster shoots and its relation to wilting of shoots infected by Erwinia amylovora. Phytopathology 68:89-94.

41. Steinberger, E. M., and Beer, S. V. 1988. Creation and complementation of pathogenicity mutants of Erwinia amylovora. Mol. Plant-Microbe Interact. 1:135-144.

42. Thoelen, M., Noben, J. P., Robben, J., Valcke, R., and Deckers, T. 2008 Comparative proteome analysis of four Erwinia amylovora strains with different pathogenicity. Acta Hortic. 793:183-185.

43. Triplett, L., Zhao, Y. F., and Sundin, G. W. 2006. Genetic differences among blight-causing Erwinia species with differing host specificities identified by suppression subtractive hybridization. Appl. Environ. Microbiol. 72:7359-7364.

44. Valdivia, R. H., and Falkow, S. 1997. Fluorescence-based isolation of bacterial genes expressed within host cells. Science 277:2007-2011.

45. Van der Zwet, T. 2006. Present worldwide distribution of fire blight and closely related disease. Acta Hortic. 704:35-36.

46. Van der Zwet, T., and Wells, J. M. 1993. Application of fatty acid class analysis for the detection and identification of Erwinia amylovora. Acta Hortic. 388:233.

47. Vanneste, J. L. 2000. Fire Blight: The Disease and Its Causative Agent, Erwinia amylovora. CABI Publishing, New York.

48. Vantomme, R., Swings, J., Goor, M., Kersters, K., and De Ley, J. 1982. Phytopathological, serological, biochemical and protein electrophoretic characterization of Erwinia amylovora strains isolated in Belgium. Phytopathol. Z. 103:349-360.

49. Wang, D., Korban, S. S., and Zhao, Y. F. 2009. The Rcs phosphorelay system is essential for pathogenicity in Erwinia amylovora. Mol. Plant Pathol. 10:277-290.

50. Wei, Z., and Beer, S. V. 1995. hrpL activates Erwinia amylovora hrp gene transcription and is a member of the ECF subfamily of sigma factors. J. Bacteriol. 177:6201-6210.

51. Wei, Z., Kim, J. F., and Beer, S. V. 2000. Regulation of hrp genes and type III protein secretion in Erwinia amylovora by HrpX/HrpY, a novel two-component system, and HrpS. Mol. Plant-Microbe Interact. 11:12511262.

52. Wei, Z. M., Laby, R. J., Zumoff, C. H., Bauer, D. W., He, S. Y., Collmer, A., and Beer, S. V. 1992. Harpin, elicitor of the hypersensitive response produced by the plant pathogen Erwinia amylovora. Science 257:85-88.

53. Zhao, Y. F., Blumer, S. E., and Sundin, G. W. 2005. Identification of Erwinia amylovora genes induced during infection of immature pear tissue. J. Bacteriol. 187:8088-8103.

54. Zhao, Y. F., He, S.Y., and Sundin, G. W. 2006. The Erwinia amylovora avrRpt $_{E A}$ gene contributes to virulence on pear and AvrRpt $2_{\mathrm{EA}}$ is recognized by Arabidopsis RPS2 when expressed in Pseudomonas syringae. Mol. Plant-Microbe Interact. 19:644-654.

55. Zhao, Y. F., Sundin, G. W., and Wang, D. 2009. Construction and analysis of pathogenicity island deletion mutants of Erwinia amylovora. Can. J. Microbiol. 55:457-464.

56. Zhao, Y. F., Wang, D., Nakka, S., Sundin, G. W., and Korban, S. S. 2009. Systems level analysis of two-component signal transduction systems in Erwinia amylovora: Role in virulence, regulation of amylovoran biosynthesis and swarming motility. BMC Genomics 10:245. 